\title{
Microbiology and Chemical Quality of Drinking Water From Household- Level Distribution Network
}

\author{
Suryatri Darmiatun \\ Center of Development and Empowerment for Automotive and Electronic Teachers and Education Staffs of Malang.
}

\section{Abstract}

Quality of most of drinking water supply from the household-level distribution network deteriorates before being distributed to the consumers. The water supply was not hygenic, tasted bad and had strong odor. The purpose of this study was determining the microbiological and chemical contamination of drinking water from distribution network. The study was a descriptive study which employed documentation as the data collection method. Parameters that will be analized were microbiological and chemical quality. The data analysis method was descriptive analysis was used. The findings showed some potential contaminations such as (1) the indicators of the biological quality of the water were the number and growth of bacteria in the biofilms (bacterial colony formation) triggered by temperature of water, nutrients in the water, quality of the pipe, and water flow; (2) the indicators of the chemical quality of the water were Volatile Organic Compounds (VOCs) substance exposure, Assimilable Organic Carbon (AOC) and loss of metal from the type of pipe used. The preventive measures were to evaluate quality of drinking water before being distributed to the household-level network, conduct certain method of water treatment when necessary, analyze materials and characteriristics of the water pipes, install the pipes appropriately, conduct the pressure test for control and maintenance for the utilities (tap).

Keywords: biofilm, drinking water, pipe

\section{INTRODUCTION}

WHO stated that quality of drinking water is one of the essential elements to maintain one's health. Maintaining quality of drinking water has always become preventive measure and methodto control disease spread through water. Water is vital but at the same time it can transfer disease to more than one places or more than one people. Studies have shown that drinking contaminated water, be it the water contaminated by viruses/ bacteria or poisonous chemical substances, may result in various healh disease such as diarrhea, cholera, typhoid fever, dysentery, cancer and skin problems.Diarrhea is the most frequently-spread disease through water. It is estimated that there are 4.6 billion cases of diarrhea that cause 2.2 million of death annually [1].

Drinking water supply through closed distribution network (pipes) is one of the government commitments to provide access to drinking water that meets the health requirement. The Municipal Waterworks (Perusahaan Daerah Air Minum) is the public

Correspondence address:

Suryatri Darmiatun

Email : atuntasrial@gmail.com

Address : Center of Development and Empowerment for Automotive and Electronic Teachers and Education Staffs of Malang institution responsible for supplying drinking water to the society. The Municipal Waterwork all over Indonesia has the same issues, low coverage level and high uncounted water. The percentage of the loss of water in Indonesia is above $30 \%$. Different drinking water supply system used by the society results in different quality and quantity of the drinking watersince the performance of each system depends on both technical and non-tecnical issues. The closed drinking water supply system (pipes) relies upon the condition of pipes and service. On the other hand, the non-pipe drinking water supply system depends on the environment. Lack of water debit, lack of water pressure and inconsistent service (water only ran at certain time of the day) bring some negative effects to the society [2].

Quality of most of the drinking water supply for household and the industry deteriorates before being distributed to the consumers due to bacterial and chemical contamination from the drinking-water installation or contamination from the bacteria grown on the broken or leaked waterpipes. The bacteria or other pollutants contaminated the drinking water thorugh cracks or holes on the pipes. However, high population of bacteria in the drinking-water distribution system is indicated by utility issue since the implication is non-hygenic water with strong taste and odor [1]. 
Pipes and storage system in the drinkingwater distribution system result in complex network as well as uncontrollable physical, chemical and biological reactions that leads to significantly different quality of water. Even though the water sources have been protected and modernized, well-maintained drinking-water installation will result in qualified drinking water; poorly maintained and dated distribution system may cause deterioriating drinking water that may cause serious health problems [3].

It is expected that the study identifies source and factors that potentially deteriorate quality of drinking water from the distribution network prior to distribution to the household as hold as formulates some preventive measures.

\section{METHODOLOGY}

The study was a qualitative study where documentation became the data collection method. The method of data analysis was descriptive.

\section{Data Collection Method}

Documentation was the data collection technique. The primary sources of data were scientific journals published directly by the researchers and the Ministry of Public Health regulations. The secondary sources of data were journals, proceedings, working paper and annual reports published by social or public institutions.

Microbiological and formation of biofilms and chemical quality of water were study parameters. Some journals have discussed some parameters related to the focus of the study. [1], [10], and [5] identified the levels of pollution with counting total coliform. [4], [5], [14], [13], [17], [15], [8], [9], [16] stated that biofilm is responsible for the deterioration of microbial water quality. [1], [10], [5], [14], and [16] tested chemical parameters that could potentially trigger the growth of bacteria. [12] identified heavy metals in the samples of drinking water from various sources. [4], [17], and [9] studied both chemical parameters that could potentially trigger the growth of bacteria and the occurrence of heavy metals in the samples of drinking water.

The data analysis technique was content analysis. HPC obtained through the pour plate technique, the result of growing colonies counted by using a colony counter. Results expressed as Colony Forming Units (CFU). Indicators chemical parameters for drinking water quality of household-level distribution network that was most relevant is the Volatile
Organic Compounds (VOCs) and Assimilabe Organic Carbon (AOC). An important indicator of biological parameters for drinking water through distribution channels are counting biomass of bacteria (biofilm) with Heterotrophic Plate Count (HPC). Gas chromatography (GC, Gas Chromatography) was a method of selection instrument. $A O C$ was analyzed using a Total Organic Carbon (AOC) analyzer. Atomic Absorpsion Spectroscopic (AAS) method was used to analyze metals ion released from drinking water distribution pipe. The results of chemical analysis and microbiological later analyzed descriptively to find the tendency of and relationship with each of the variables studied.

\section{FINDINGS AND DISCUSSION}

Quality of drinking water from the closed distribution system (pipes) is influenced by numerous factors and may result in microbial or chemical contamination in the drinking water.

Metal pipe such as copper was frequently used for household plumbing system. However, polymer pipes such as cross-linked polyethylene (PEX), polyethylene (PE), and polyvinyl chloride (PVC), have recently been used for water supply system. The polymer pipes were more affordable and easy to install. However, pipe materials have a significant effect on the physico-chemical characteristics of corrosion scales and sequentially the water quality variations in water distribution system (WDS) [11]. Substance in the plastic pipe may leach and cause some health and aesthetic issues for instance unwanted taste or odor.

Heterotrophic Plate Count (HPC) was used for bacterial analysis and Colony Forming Units (CFU) is the means of analysis to count bacterial colony per $\mathrm{cm}^{2}$ of the media. HPC is higher in hot water compared to cold water in the cross-linked polyethylene (PEX) and copper pipes. Coliform bacteria grew better on the PEX pipes than the copper pipes. It indicated that the type of pipe and water temperature determined the growth of bacteria in the water distribution system [4].

Brownish deposit was found in connection spot when the shower head was inspected. The deposit became biofilm habitat. HPC level on the shower head is determined by how often the consumers clean, repair or change the shower heads[4]. The utility itself was the overarching factor in shaping the building plumbing microbiome; environment (location) quality in the distribution system, plumbing material, and 
stagnation length events also had a significant influence. Total chlorine concentration, $\mathrm{pH}, \mathrm{P}$, $\mathrm{SO}_{4}{ }^{2-}$ and $\mathrm{Mg}$ together explained greatest variation in microbiome at multi-utility level [9].

Several bacteria can only die on certain temperature, and the bacteria grown on the biofilm were resistant to chlorine. One should identify the bacteria running water may contain in order to decide appropriate preventive measure for example when preparing food. Food and beverage industry should maintain the water they use since boiling the water cannot kill some bacteria. Bacterial growth in biofilms was stimulated by the heating of the tap water [4].

High residence time could cause decay of water quality as it had been responsible for increment in the rate of bacteria growth (HPC). Increasing nutrients affected multiplication of microorganisms in the water distribution system. To ensure both chemical and microbial quality of water, water should be flushed before use after stagnation [17].

Flushing the pipes and addition of chlorine would be very useful in controlling the growth of biofilms in the water distribution systems. Both shock chlorination and hydrodynamic stress (flushing the pipe) cause partial erosion of the biofilm as it lost more than half of its bacterial cells [8]. High velocity could cause increased turbidity and corrosion rate in the water distribution system and could lead to decline in water quality in the distribution systems. The high turbidity makes chlorine lose its efficiency even if residual chlorine is high. This happens because when turbidity is high, coli forms will be attached to the particles and chlorine would not be able to reach and kill the bacteria [5].

However, excessive concentration in drinkingwater supply may become serious health challenge. Yet, the value was depreciated as the water was distributed using the pipe distribution system. Other study showed dosage of chlorine decreased $50 \%$ after 25 hours when the temperature was $25^{\circ} \mathrm{C}$. The decrease may influence effectiveness of chlorine in preventing pathogen from the sources of drinking water, which may have serious health implication [3].

Chlorine residual contributed to germicidal effect, and constant application would increase resistance to these chemicals. Once the residual disinfectant has decayed, biofilms reach a common established community equilibrium [15]. Dominant bacteria had high resistance towards heat or disinfectant or were opportunistic microorganism. Hence the procedure of flushing the pipes and addition of chlorine should be appropriate to the process effectively.

Free chlorine is an important oxidizing agent used to kill microbes during the disinfection process to ensure the safety of drinking water. On the other hand, chlorine in the tap water may increase Assimilable Organic Carbon (AOC) level. $A O C$ is one of the most important factors affecting the regrowth of microorganisms in drinking water, thereby increasing the potential for microbial regrowth in the pipe network. Microfilm method may control HPC as effective as chlorine. After microfiltration, the amount of HPC in the pipeline decreased [4]. Nutrient availability may change with various physical conditions, such as methods or treatment applied.

Studies indicated that Volatile Organic Compounds (VOCs) were found in the water running through the polybutylene (PB), PVC, polypropylene (PP), polyethylene (PE) and Chlorinated Polyvinyl Chloride (CPVC) pipes. Skjevrak et al. reported that the VOCs in the biofilm on the high-density polyethylene (HDPE) pipes contributed to the taste in drinking water. Styrene, which may be toxic to the gastrointestinal tract, kidney, and respiratory system, was detected in the PEX, PB, PP, PE, PVC, CPVC, copper and stainless steel pipes. Styrene was known to have a specific taste. Heim said that the pipes with polymer-based material contributed to unwanted odor and Total Organic Carbon (TOC) level in the water [4].

Exposure to few heavy metals (e.g., As, Cd, and $\mathrm{Pb}$ ) is a pressing issue due to the significant risks to human health. Co-exposure to multiple heavy metals must be carefully studied for synergistic or antagonistic effects [12]. Metal concentration in the current plastic pipes were not as serious except in the PVC and CPVC pipes. Lead was detected in the current CPVC and PVC pipes. UV radiation accelerated migration of lead from the PVC pipes. The use of stainless steelpipes in the water distribution system had some advantageous such as low corrosion, hygienic water supply and aesthetic [4].

There was more metals leaching at the hot water system compared to the cold water system (nickel, copper, zinc) but also increased metal concentrations (lead and zinc) were found to leach from brass products in cold stagnated waters. During the first year of operation, several metals had leached into the water from brass components (lead and zinc), water fittings of the 
hot water systems' components (nickel) or pipeline materials (copper) [17].

Lead came primarily from household plumbing system in which solder, fittings or service pipe connections to homes contained lead. PVC pipe also contained lead compounds that could separate and produced high concentrations of lead in drinking water. The iron content in the water was the result of corrosion and oxidation of the metal-based materials such as iron. The corrosion formed sediment in the water. The dated pipeline distribution system led to the dissolution of copper, zinc and cadmium [3].The impacts of zinc coatings lead to the much high $\mathrm{Zn}$ content and zinc compounds formation [11].

Increasing contamination in the water distribution system happened due to broken or leaking distribution pipes, contamination from septic tanks or other waste around the distribution pipes, slow flow of water or idle time of the water in the pipe. It is recommended to conduct the pressure test for the pipes to any damage and decide when maintenancthe necessary care. Water should be distributed in the quality and the right pressure all the time in order to avoid backsiphonage [1].

Contamination may be prevented as long as the water pressure in the pipe was maintained carefully. Nevertheless, leakage should be avoided since it may increase the risk for contamination. The findings of the study described there were some factors why the drinking water from the pipping system could not meet the clean water requirement. They were:

1. Hygine of the Municipal Waterworks reservoir,

2. Local contamination in the wáterpipping system,

3. Distance between the pipelines and the Municipal Waterworks processing system [6].

Three factors that guaranteed the quality of water from the water distribution system. The first was regulation; related to the plumbing system, the government had established the 2000 SNI 03-6481-2000 on Plumbing System, and the 2005 SNI 03-7065-2005 on Plumbing System Planning. The second was human resource; the public institution needed competent staffs that had competence in every field of work from building planners to construction workers. For water engineering and management, helping lay the groundwork needed to identify critical factors that may be manipulated in the future to beneficially manage the building plumbing microbiome [9]. The third was industrial factor. It was expected that the industry produced equipment that met the sanitary standards. The facts showed that the need and use of energy and water in some buildings were increasing so when we did not use water wisely, it may cause damage to the environment [7].

\section{CONCLUSION}

Conclucions include the followings:

- Pipe material was the main factor in driving bacterial community and has a significant effect on the physico-chemical characteristics of corrosion scales and sequentially the water quality variations in water distribution system (WDS).

- Shock chlorination and hydrodynamic stress cause partial erosion of the biofilm.

- Chlorination and microfiltration reduced biofilm formation, as measured by HPCs on pipe walls.

- Ineffective chlorination increased Assimilable Organic Carbon (AOC) level, is one of the most important factors affecting the regrowth of microorganisms in drinking water.

- The utility itself was the overarching factor in shaping the building plumbing microbiome; environment (location) quality in the distribution system, plumbing material, temperature, and stagnation length events also had a significant influence.

- VOC substances and styrene were identified in five kinds of plastic pipes (PVC, PB, PP, PE, and cPVC).

The novelty and advantage of the study is the study described preventive measures of deteriorating quality of drinking water in the household from the potential sources of problems. The limitation of this study is the lack of data and information about plumbing and its issues. Future researchers should conduct deeper analysis about the substance and the characteristics of each type of pipes and its eligibility.

\section{ACKNOWLEDGMENT}

The researcher would like to thank the institutions for their substantial and financial support more particularly during the data collection method. It is expected that the study contribute to the body of knowledge and interest groups/ individuals. 


\section{REFERENCES}

[1]. Awopetu, MS., Coker, AO., and Aribisala, JO. 2013. Water quality in a pipe distribution network: a case study of a communal water distribution network in Ibadan, Nigeria. WIT Transactions on Ecology and The Environment: Vol 171 pp. 175-186.

[2]. Agustina, D V. 2007. Analisa Kinerja Sistem Distribusi Air Bersih PDAM Kecamatan Banyumanik Di Perumnas Banyumanik. Tesis. Universitas Diponegoro.

[3]. Ohwo. 2014. The Impact of Pipe Distribution Network on the Quality of Tap Water in Ojota, Lagos State, Nigeria. American Journal of Water Resources: Vol. 2 pp 110-117

[4]. Lee, Y. 2013. An Evaluation of Microbial and Chemical Contamination Sources Related to the Deterioration of Tap Water Quality in the Household Water Supply System. International Journal of Environmental Research and Public Health: Vol. 10, pp. 4143-4160

[5]. Shamsaei H., Jaafar O., and Basri N.E.A.. 2013. Effects Residence Time to Water Quality in Large Water Distribution Systems. Scientific Research Journal. 5, 449-457

[6]. Handarini dan Rohayati. 2010. Gambaran Bakteri Colofirm Pada Air PDAM Dengan Metode Most Probable Number (MPN) Di Komplek Mega Brata, Ciwastra, Kota Bandung. Jurnal Kesehatan rajawali: Vol. 2 pp 1-7.

[7]. Anonim. 2016. Peluncuran SNI Sistem Plumbing dalam Konstruksi Bangunan. www.pu.go.id/main/view_pdf/10045.

[8]. Mathieu L., Bertrand I., Abe Y., Angel E., Block J.C., Skali-Lami S., and Francius G.. 2014. Drinking water biofilm cohesiveness changes under chlorination or hydrodynamic stress. Water Research Journal 55, 175: 184.

[9]. Ji P., Parks J., Edwards M.A., Pruden A. (2015). Impact of Water Chemistry, Pipe Material and Stagnation on the Building Plumbing Microbiome. PLoS ONE 10(10): e0141087. doi:10.1371/journal.

[10]. Kumpel E., Nelson K. L. 2013. Comparing microbial water quality in an intermittent and continuous piped water supply. Water Research Journal XXX, 1-13.

[11]. Li M., Liu Z., Chen Y., and Hai Y. 2016. Characteristics of iron corrosion scales and water quality variations in drinking water distribution systems of different pipe materials. Water Research 106, 593-603.

[12]. Chowdhury S., Mazumder J.M.A., Al-Attas O, Husain T. 2016. Heavy metals in drinking water: Occurences, implicaions, and future needs in developing countries. Science of The Total Environment. 69-570, 476-488.

[13]. Isabel D., Joby B. B, Peter D., Raju S., Katherin E.F., and Chaterine A.B. 2014. Methodological approaches for studying the microbial ecology of drinking water distribution Systems. Water research 65, 134-156.

[14]. Douterelo I, Husband S, Boxall J.B. 2014. The bacteriological composition of biomass recovered by flushing an operational drinking water distribution system. Water Research 54, 100-114.

[15]. Jennifer L.A.S., Monis P., Fabris R., Ho L., Braun K., Drikas M., and Cooper A. 2014. Assessing the impact of water treatment on bacterial biofilms in drinking water distribution systems using high-throughput DNA sequencing. Chemosphere 117, 185192.

[16]. Sune T.R., Erik A., Hans-Christian H.L., Mikael E.O., Zuzana P., and Hans-Jørgen A. 2015. Degradation of specific aromatic compounds migrating from PEX pipes into drinking water. Water research 81, 269-278.

[17]. Jenni I., Kaunisto. T, Pursiainen A., Miettinen I.T., Kusnetsov J., Riihinen K., and Keinanen-Toivola M.M. 2014. Drinking water quality and formation of biofilms in an office building during its first year of operation, a full scale study. Water Research 49, 83-91. 